\title{
Study of Surface Ozone over an American Station for a Period of 3.5 Decade
}

\author{
Nikunj Jaitawat, Vimal Saraswat*, Nirmala Rathore \\ Department of Physics, Bhupal Nobles' University, Udaipur, India \\ Email: *vimal@bnuniversity.ac.in
}

How to cite this paper: Jaitawat, N., Saraswat, V., \& Rathore, N. (2021). Study of Surface Ozone over an American Station for a Period of 3.5 Decade. American Journal of Climate Change, 10, 422-432.

https://doi.org/10.4236/ajcc.2021.104022

Received: August 25, 2021

Accepted: December 3, 2021

Published: December 6, 2021

Copyright (c) 2021 by author(s) and Scientific Research Publishing Inc. This work is licensed under the Creative Commons Attribution International License (CC BY 4.0).

http://creativecommons.org/licenses/by/4.0/

(c) (i) Open Access

\begin{abstract}
In this research paper we have evaluated the relation between surface Ozone $\left(\mathrm{O}_{3}\right)$, Sun Spot Number (SSN) and Carbon Monoxide (CO) over an American station "Tutuila" for the long period of 35 years (1980-2015). It was analyzed that $\mathrm{CO}$ and $\mathrm{O}_{3}$ show an increasing trend over the maximum months of the year, whereas SSN shows decreasing trend throughout the year. We have concluded that, for $\mathrm{O}_{3}$ the increasing trend is found to be maximum in the month of December, whereas surprisingly just a month before it i.e., in November, the value was negative. We also analyze here the $\mathrm{CO}$ data for the same period. It is observed that the CO increases from January to June. Its increment is found to be minimum in January month and maximum in the month of April. After it, the CO shows the decay trend from July to September, and then again increases from October to December months. $\mathrm{NO}_{2}$ data of 11 years is also studied here and concluded that, the variation observed in March month is very small and is positive. In the same way, a positive trend is observed for $\mathrm{NO}_{2}$ data in June month, but in rest all the months the value is negative.
\end{abstract}

\section{Keywords}

Surface Ozone, Sunspot Number, Carbon Monoxide, Nitrogen Dioxide

\section{Introduction}

The Earth's atmosphere is split into 5 layers: troposphere, stratosphere, mesosphere, thermosphere, and exosphere (Perevedentsev et al., 2019). Many of the human activities are badly affecting the atmosphere (Lu et al., 2018), and the stratosphere layer is a matter of great concern which is harmful to human itself (Anwar et al., 2016). It has been observed from past studies that concentrations of ozone in the upper stratosphere have increased in the last 15 years (Rozema et 
al., 2005). Depletion of the ozone layer by chlorine and bromine species has been a major environmental issue (Sivasakthivel \& Reddy, 2011). The ozone layer, which absorbs and scatters the solar UV radiations, lies in this region (Brenna et al., 2019). The ozone layer is a naturally occurring gas in the region of the stratosphere, where ozone particles are accumulated (Wargan, 2018). But the thickness of the ozone layer varies with altitude and seasonal change (Davis et al., 2017). Life is protected from UV rays by the stratospheric ozone layer, which acts as a shield or sunscreen (Park et al., 2020). Surface ozone is a highly efficient greenhouse gas; its global warming potential is about 1200-2000 times that of $\mathrm{CO}_{2}$. Ozone is produced in the troposphere by photochemical oxidation of $\mathrm{CO}$ (Minschwaner et al., 2010), $\mathrm{CH}_{4}$, and Non-Methane Volatile Organic Carbons (NMVOCs) in the presence of $\mathrm{NO}_{\mathrm{x}}$ (Minschwaner \& Manney, 2015). Loss of ozone in troposphere takes place through chemical reactions and dry deposition. As an important greenhouse gas, $\mathrm{O}_{3}$ is making significant contributions to climate change. The concentration of photochemical oxidants can be decreased by controlling their precursors such as: nitrogen oxides $\mathrm{NO}_{\mathrm{x}}\left(\mathrm{NO}\right.$ and $\left.\mathrm{NO}_{2}\right)$ and Volatile Organic Compounds (VOCs) etc. (Ravishankara et al., 2009). Sunspots are areas that appear dark on the surface of the sun because of some temperature variation (Solanki, 2003). They are electrically charged gases that generate areas of powerful magnetic fields. These are regions of reduced surface temperature caused by concentrations of magnetic flux. Sunspots usually appear in pairs. The amount of solar activities changes with the stages in the solar cycle (Willett, 1962). Observational evidence for a relation between atmospheric total ozone amount and sunspot number (SSN) has been presented and debated for more than two decades (Angell, 1989).

Generally, ozone production depends on several factors such as temperature, solar activity, wind, speed, and direction (Fleming et al., 2020). This work represents the influence of solar activity. However, previous studies have shown that ozone formation totally depends on the activities taking place on sun such as sunspots, solar winds, etc., which can alter the concentration of ozone (Arsenovic et al., 2018). They affect human health and have an impact on climatic change. One of the various problems caused by air pollution in urban areas is photochemical oxidants. The formation of ground-level ozone depends on several factors like, the intensity of solar radiation, the concentrations of $\mathrm{NO}_{\mathrm{x}}$ and VOCs, and also on the ratio of $\mathrm{NO}_{\mathrm{x}}$ to VOCs (Qin et al., 2004). Variability of ground air temperature, wind speed and direction, relative humidity, and precipitation associated with climate change have the potential to affect the distribution and deposition of $\mathrm{O}_{3}$. Nitrogenous compounds emitted by humans in a small amount like NO, $\mathrm{N}_{2} \mathrm{O}$ and $\mathrm{NO}_{2}$ are considered to be most responsible for the depletion of the ozone layer (Zoran et al., 2020). Nitrous oxide is also a greenhouse gas, so reducing its emission from man-made sources would be good for both the ozone layer and climate. A study on Arctic and Antarctic ozone depletion has helped us in understanding ozone depletion more clearly (Solomon et al., 2014; Tilmes et al., 2005; Dameris et al., 2021; Bernhard et al., 2020). The main causes of 
ozone depletion are chlorofluorocarbons (CFCs), HCFCs and halons, apart from it $\mathrm{CO}$ and $\mathrm{NO}_{\mathrm{x}}$ also affect the stratospheric and tropospheric ozone, so here in the present study our main focus is only on the $\mathrm{CO}$ and $\mathrm{NO}_{\mathrm{x}}$. Since the stratospheric ozone is formed by molecular ozone in the presence of solar UV radiation and hence solar activity i.e., the sunspot number, which represents how the sun is active, plays a major role. So, we have discussed the relation between ozone, sunspot number, $\mathrm{NO}_{2}$ and $\mathrm{CO}$ data. This paper explores the interactions between these gases and stratospheric ozone.

\section{Data Set and Site Description}

For the present study, we required sufficient long-term data for a station, so we choose an American station "Tutuila" (Figure 1). A sufficient amount of ozone data for this station is available on https://www.esrl.noaa.gov/ this data were actually collected at ground by earlier researcher and hence the ozone data, which we used here is surface ozone, and now data is worldwide available on net. So here we called it ground based satellite ozone data. It means in our present study

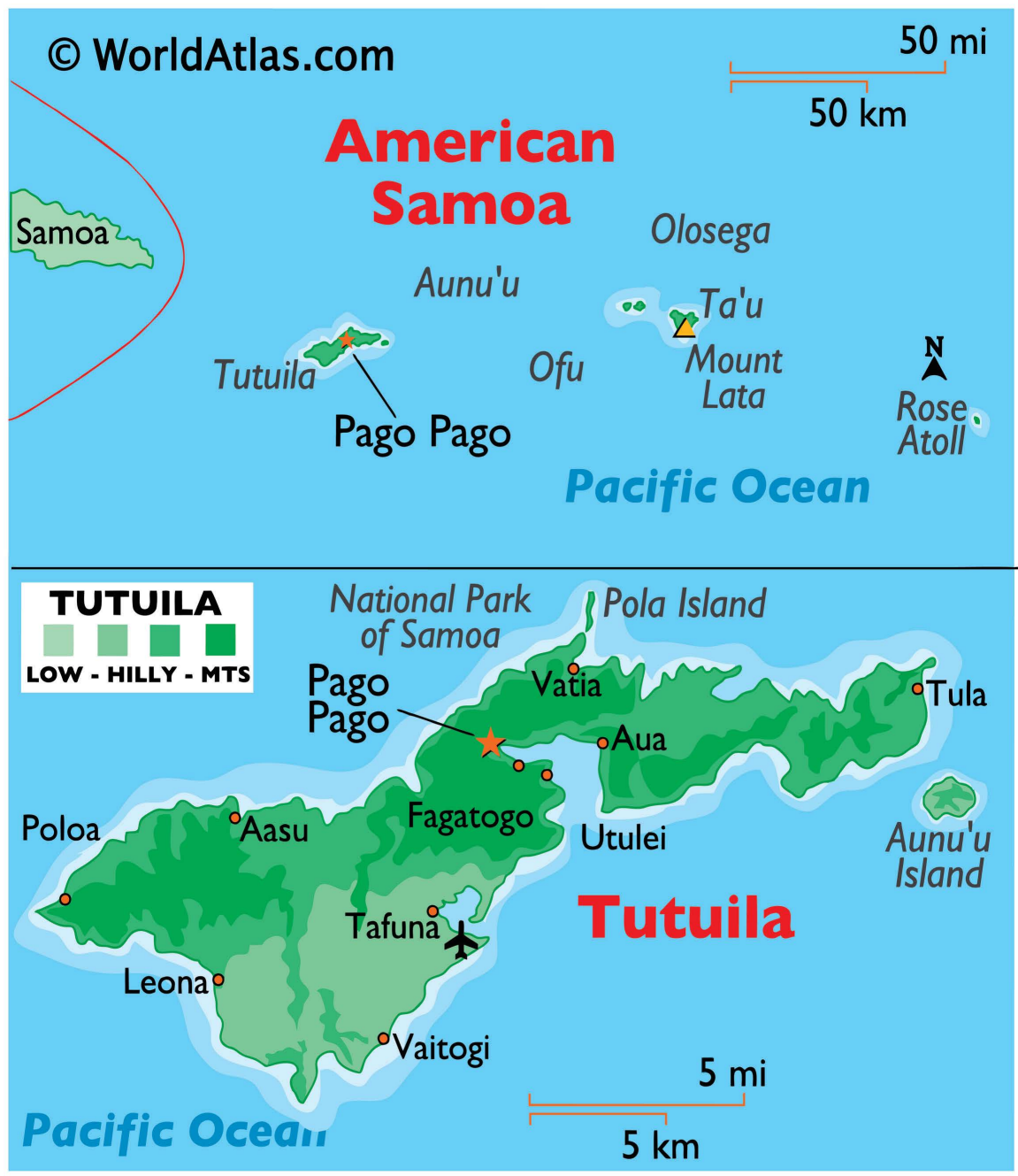

Figure 1. Location map of the Tutuila. 
we used surface ozone, which were collected at American station "Tutila" and this data is retrieved from https://www.esrl.noaa.gov/. The ESRL Global Monitoring Division has been measuring surface ozone at several global locations since 1973. Tutuila is the main and the largest island of American Samoa. It is the third-largest island in the Samoan Islands chain of the Central Pacific. It is located roughly 4000 kilometers northeast of Brisbane, Australia, and lies something over 1200 kilometers to the northeast of Fiji. The American Samoa Observatory (SMO) is located in the middle of the South Pacific, about midway between Hawaii and New Zealand and its coordinates are $14.295^{\circ} \mathrm{S}, 170.70^{\circ} \mathrm{W}$. The observatory is situated on the northeastern tip of Tutuila Island, American Samoa, at Cape Matatula. The observatory was established in 1974 on a 26.7 -acre site.

The CO data for the current study is downloaded from https://giovanni.gsfc.nasa.gov/. Giovanni is a tool that displays earth science data from NASA satellite directly on the internet. We have selected time series, areaaveraged data of American station Tutuila, the same station for which ozone data was collected. For a comparative study of $\mathrm{O}_{3}$, SSN and CO we have downloaded CO surface concentration data for the same period of 35 years from 1980 to 2015. The source used for this data is MERRA-2 model and of spatial resolution $0.5 \times 0.625$ degree in the unit of ppbv. $\mathrm{NO}_{2}$ data for the period of 11 years from 2005-2015 is downloaded from the same site and for the same station i.e., Tutuila. The source used for this data is OMI and spatial resolution of 0.25 degree in the unit of $1 / \mathrm{cm}^{2}$.

\section{Methodology}

For analyzing the data, we have selected one American station "Tutuila" and downloaded ozone data of the years 1980 to 2015 from the above-mentioned site. This data includes everyday hourly ground base ozone data. For better comparative study, $\mathrm{SSN}, \mathrm{CO}$, and $\mathrm{NO}_{2}$ data are also downloaded for the same period of the same station from their respective sites.

All the raw data downloaded was in grid form, which we have converted into the appropriate form. Further, we have calculated the monthly mean for every year data and got 12 data values i.e., one for each month. After it, we have plotted the monthly mean values of all the three substituent $\left(\mathrm{O}_{3}, \mathrm{CO}, \mathrm{SSN}\right)$ against the years, so that the variation in all the three substituent can be easily concluded. The results obtained from each graph i.e., the slope and correlation coefficient for each month are collected and mentioned them in tabulated form. Similar graphs for $\mathrm{NO}_{2}$ data are also drawn. The result and conclusion obtained based on this study are given in the next section.

\section{Result and Discussion}

The monthly mean variation in $\mathrm{CO}, \mathrm{O}_{3}$, SSN with years are shown in Figure 2 . This variation is for 35 years i.e., from 1980 to 2015.

It is observed from these figures and Table 1 that the value of surface ozone 


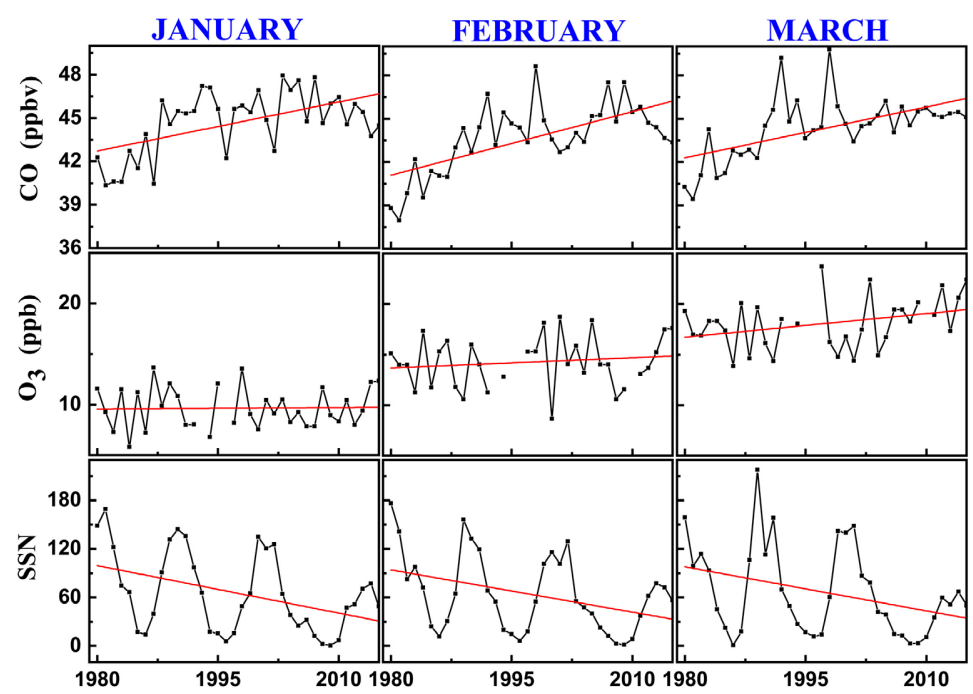

(a)

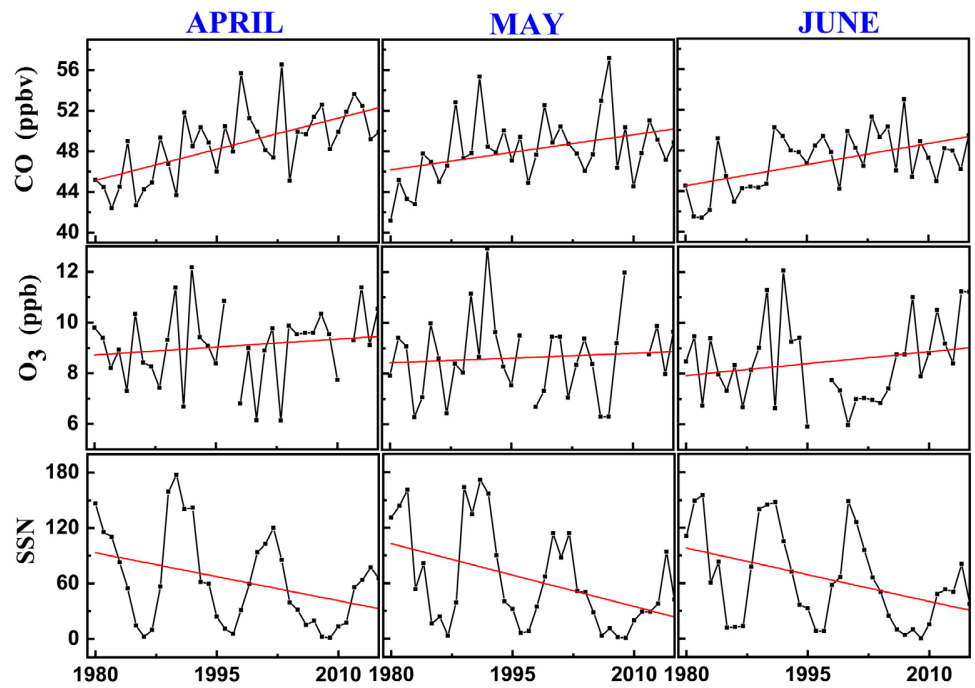

(b)

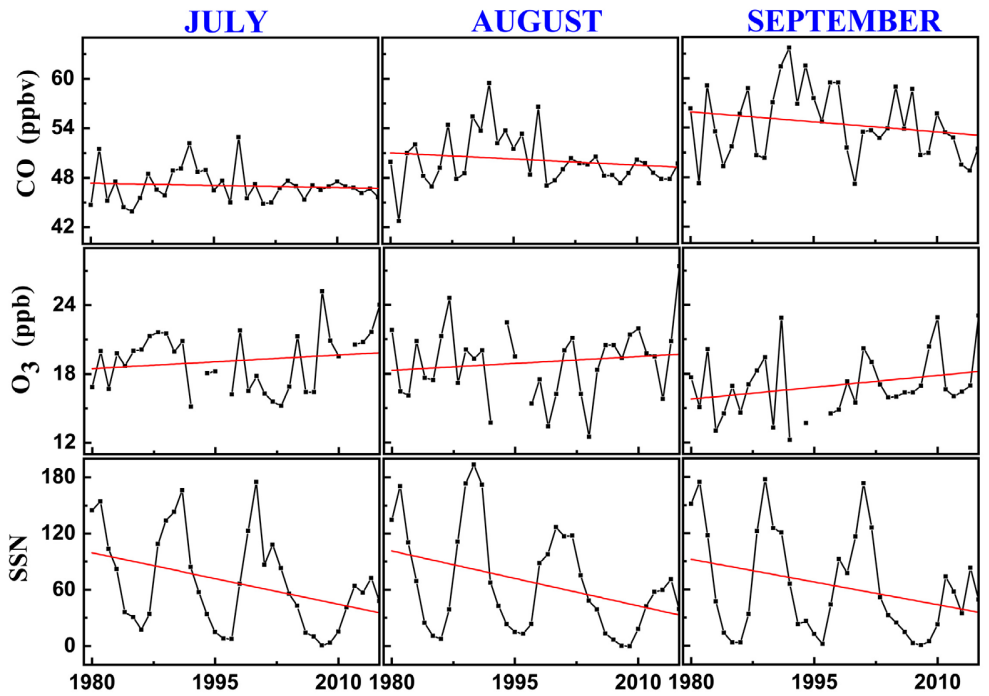

(c) 


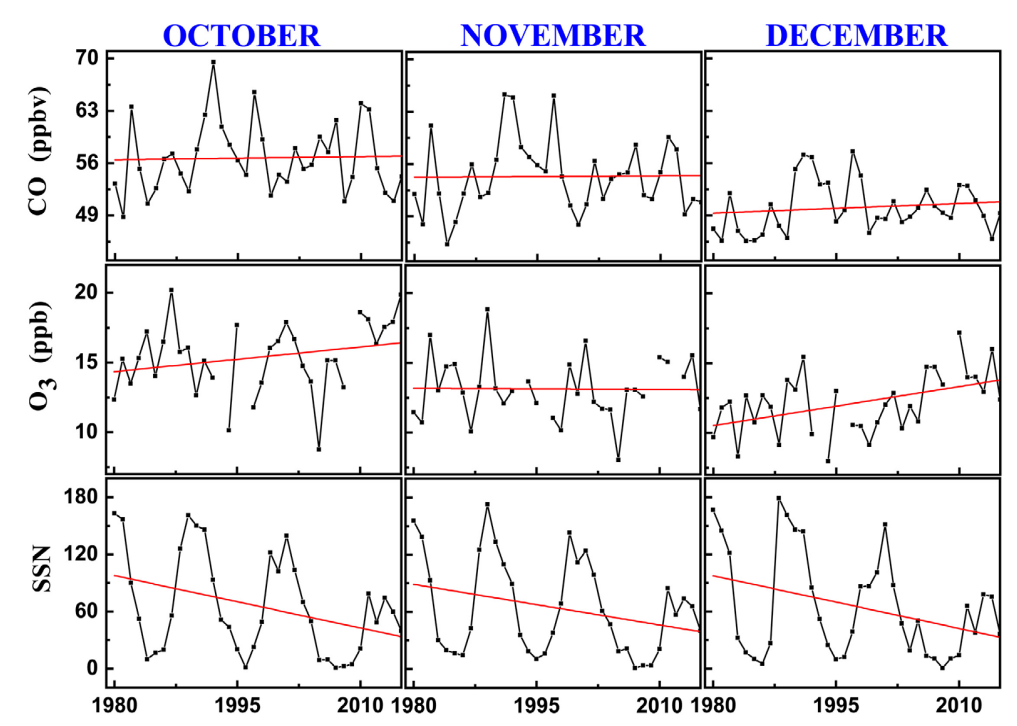

(d)

Figure 2. The variation of CO, $\mathrm{O}_{3}$ and SSN from year 1980 to 2015 in a specific month.

Table 1. Slope of $\mathrm{O}_{3}, \mathrm{SSN}$ and CO over different months.

\begin{tabular}{cccc}
\hline Months & $\mathrm{O}_{3}$ & $\mathrm{SSN}$ & $\mathrm{CO}$ \\
\hline January & 0.00484 & -1.95396 & 0.11313 \\
February & 0.03412 & -1.73911 & 0.14663 \\
March & 0.07799 & -1.81283 & 0.11735 \\
April & 0.02079 & -1.73051 & 0.20437 \\
May & 0.01248 & -2.26584 & 0.11514 \\
June & 0.03106 & -1.92658 & 0.1385 \\
July & 0.03965 & -1.82296 & -0.01759 \\
August & 0.03981 & -1.94987 & -0.04938 \\
September & 0.06877 & -1.61318 & -0.08106 \\
October & 0.05886 & -1.8381 & 0.01371 \\
November & -0.003 & -1.42378 & 0.00678 \\
December & 0.09357 & -1.84634 & 0.0429 \\
\hline
\end{tabular}

increases and shows a linear increment. The maximum growth in ozone value is observed in December, and it is found to be 0.09357 and the minimum growth is observed in January, which is 0.00484 . The decaying trend i.e., the negative trend is shown by ozone in November which is -0.003 . Similarly, from graphs, we conclude that $\mathrm{CO}$ value shows a decreasing trend in the monsoon period of July, August, and September, whereas for the rest of the year its value shows an increasing trend with maximum growth in April with a value 0.20437 and minimum growth in the month of November with value 0.00678 . We also observe that SSN value shows decreasing trends throughout the whole year with a max- 
imum value of -1.42378 in the month of November and a minimum value of -2.26584 in May. Hence, we conclude that Ozone and CO show an increasing trend, while SSN shows a decreasing trend over 12 months.

From Table 2, we observe that the correlation between $\mathrm{O}_{3}$ and $\mathrm{SSN}$ is found to be positive in January, February, April, May, September, October, and November with the highest positive value of 0.2725 in month of November and the lowest positive value of 0.0267 in May. We also observe a negative correlation between $\mathrm{O}_{3}$ and SSN in the rest of the five months i.e., March, June, July, August, and December with a highest negative correlation of -0.04275 in March and the lowest negative correlation of 0.2912 in June. Hence observing this trend, we conclude that for maximum months the correlation between $\mathrm{O}_{3}$ and SSN is highly positive. Now studying about the correlation between $\mathrm{O}_{3}$ and $\mathrm{CO}$, from Table 2 we observe that maximum months through the whole year shows a negative correlation. It is found to be negative in January, February, March, April, May, September, October, and November months with the highest negative correlation of -0.0634 in February and lowest negative correlation of -0.26511 in January, whereas in rest of the months it shows positive correlation.

The monthly mean variation for $\mathrm{NO}_{2}$ is shown in Figure 3. This variation is for 11 years i.e., from the year 2005 to 2015. It is observed from the figure that the value of $\mathrm{NO}_{2}$ shows different trends every month. Maximum months show the decaying trend, the highest decay is observed in November and the lowest decay is observed in August and their values are -8.2087E12 and -1.0442E12 respectively. The variation observed in March is very small and it is found to be positive i.e., 1.4481E12. In the same way, a positive trend is also observed in $\mathrm{NO}_{2}$ data in June month and its growth rate is $3.4360 \mathrm{E} 12$. On the basis of correlation between $\mathrm{O}_{3}$ and $\mathrm{NO}_{2}$ it is found that there is not a particular relation between

Table 2. Correlation of $\mathrm{O}_{3}$ with $\mathrm{SSN}$ and $\mathrm{CO}$ over different months.

\begin{tabular}{ccc}
\hline Months & $\begin{array}{r}\text { Correlation between } \mathrm{O}_{3} \\
\text { and SSN }\end{array}$ & $\begin{array}{c}\text { Correlation between } \mathrm{O}_{3} \\
\text { and CO }\end{array}$ \\
\hline January & 0.080472 & -0.26511 \\
February & 0.235077 & -0.06346 \\
March & -0.04275 & -0.119 \\
April & 0.036025 & -0.24857 \\
May & 0.026713 & -0.16902 \\
June & -0.2912 & 0.026791 \\
July & -0.1316 & 0.13152 \\
August & -0.17093 & 0.100537 \\
September & 0.193345 & -0.12676 \\
October & 0.035231 & -0.22733 \\
November & 0.272573 & -0.12313 \\
December & -0.1415 & 0.118135 \\
\hline
\end{tabular}



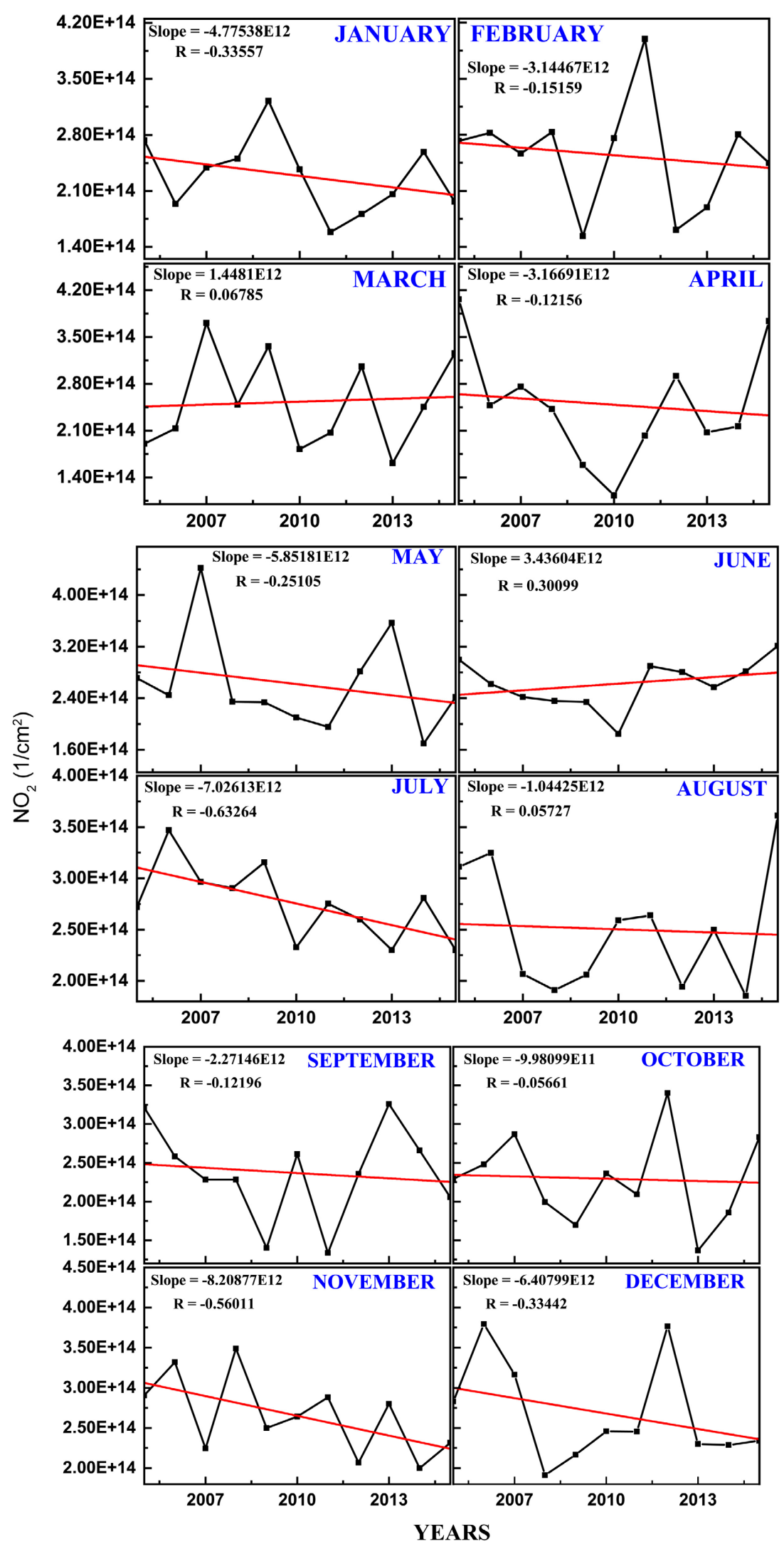

Figure 3. The variation of $\mathrm{NO}_{2}$ from year 2005 to 2015 in a specific month in terms of per $\mathrm{cm}^{2}$. 
these two gases. In some months we got a positive correlation and in other months we got a negative correlation. In February and July months we got physically accepted negative correlation, which are about -0.66 and -0.43 respectively, and in August month a positive correlation of about 0.41, whereas in rest of the months the value of Pearson correlation coefficient is found to be very less, which is not physically accepted.

\section{Conclusion}

On the basis of present study, in which we analyzed a data of about 35 years raging from 1980 to 2015 of Tutuila (American station) we can conclude that $\mathrm{CO}$ and $\mathrm{O}_{3}$ show an increasing trend over the maximum months of the year, whereas SSN shows decreasing trend throughout the year.

Ozone shows the maximum increasing trend in December month, whereas in the previous month of it i.e., in November month it shows a negative trend.

If we see the CO data for the same period then it is observed that the value of it increases from January to June and its value is found to be minimum in January month and maximum in the April. The decaying trend of $\mathrm{CO}$ is observed from July to September, and after it i.e., from October to December months it again increases, but its growth rate is very small.

The analyzed 11 years data of $\mathrm{NO}_{2}$ concluded that, the variation observed in March month is very small and is positive. In the same way, a positive trend is observed for $\mathrm{NO}_{2}$ data in June month, but in rest all the months the value is negative. The correlation between $\mathrm{O}_{3}$ and $\mathrm{NO}_{2}$ shows that both are negatively correlated in some months and positively correlated in some other months. The negative correlation value between these two gases is found to be physically accepted only in the month of February and July, and positively physically accepted value in the month of August only.

\section{Conflicts of Interest}

The authors declare no conflicts of interest regarding the publication of this paper.

\section{References}

Angell, J. K. (1989). On the Relation between Atmospheric Ozone and Sunspot Number. Journal of Climate, 2, 1404-1416. https://doi.org/10.1175/1520-0442(1989)002<1404:OTRBAO >2.0.CO;2

Anwar, F., Chaudhry, F. N., Nazeer, S., Zaman, N., \& Azam, S. (2016). Causes of Ozone Layer Depletion and Its Effects on Human: Review. Atmospheric and Climate Sciences, 6, 129-134. https://doi.org/10.4236/acs.2016.61011

Arsenovic, P., Rozanov, E., Anet, J., Stenke, A., Schmutz, W., \& Peter, T. (2018). Implications of Potential Future Grand Solar Minimum for Ozone Layer and Climate. Atmospheric Chemistry and Physics, 18, 3469-3483. https://doi.org/10.5194/acp-18-3469-2018

Bernhard, G. H., Fioletov, V. E., Grooß, J. U., Ialongo, I., Johnsen, B., Lakkala, K., Man- 
ney, G. L., Müller, R., \& Svendby, T. (2020). Record-Breaking Increases in Arctic Solar Ultraviolet Radiation Caused by Exceptionally Large Ozone Depletion in 2020. Geophysical Research Letters, 47, e2020GL090844. https://doi.org/10.1029/2020GL090844

Brenna, H., Kutterolf, S., \& Krüger, K. (2019). Global Ozone Depletion and Increase of UV Radiation Caused by Pre-Industrial Tropical Volcanic Eruptions. Scientific Reports, 9, Article No. 9435. https://doi.org/10.1038/s41598-019-45630-0

Dameris, M., Loyola, D. G., Nützel, M., Coldewey-Egbers, M., Lerot, C., Romahn, F., \& van Roozendael, M. (2021). Record Low Ozone Values over the Arctic in Boreal Spring 2020. Atmospheric Chemistry and Physics, 21, 617-633. https://doi.org/10.5194/acp-21-617-2021

Davis, S. M., Hegglin, M. I., Fujiwara, M., Dragani, R., Harada, Y., Kobayashi, C., Long, C., Manney, G. L., Nash, E. R., Potter, G. L., Tegtmeier, S., Wang, T., Wargan, K., \& Wright, J. S. (2017). Assessment of Upper Tropospheric and Stratospheric Water Vapor and Ozone in Reanalyses as Part of S-RIP. Atmospheric Chemistry and Physics, 17, 12743-12778. https://doi.org/10.5194/acp-17-12743-2017

Fleming, E. L., Newman, P. A., Liang, Q., \& Daniel, J. S. (2020). The Impact of Continuing CFC-11 Emissions on Stratospheric Ozone. Journal of Geophysical Research: At mospheres, 125, e2019JD031849. https://doi.org/10.1029/2019JD031849

Lu, X., Hong, J., Zhang, L., Cooper, O. R., Schultz, M. G., Xu, X., Wang, T., Gao, M., Zhao, Y., \& Zhang, Y. (2018). Severe Surface Ozone Pollution in China: A Global Perspective. Environmental Science \& Technology Letters, 5, 487-494. https://doi.org/10.1021/acs.estlett.8b00366

Minschwaner, K., \& Manney, G. L. (2015). Derived Methane in the Stratosphere and Lower Mesosphere from Aura Microwave Limb Sounder Measurements of Nitrous Oxide, Water Vapor, and Carbon Monoxide. Journal of Atmospheric Chemistry, 71, 253-267. https://doi.org/10.1007/s10874-015-9299-Z

Minschwaner, K., Manney, G. L., Livesey, N. J., Pumphrey, H. C., Pickett, H. M., Froidevaux, L., Lambert, A., Schwartz, M. J., Bernath, P. F., Walker, K. A., \& Boone, C. D. (2010). The Photochemistry of Carbon Monoxide in the Stratosphere and Mesosphere Evaluated from Observations by the Microwave Limb Sounder on the Aura Satellite. Journal of Geophysical Research: Atmospheres, 115, D13303. https://doi.org/10.1029/2009JD012654

Park, S., Son, S. W., Jung, M. I., Park, J., \& Park, S. S. (2020). Evaluation of Tropospheric Ozone Reanalyses with Independent Ozonesonde Observations in East Asia. Geoscience Letters, 7, Article No. 12. https://doi.org/10.1186/s40562-020-00161-9

Perevedentsev, Y. P., Shantalinskii, K. M., Sherstyukov, B. G., \& Guryanov, V. (2019). Current Climatic Changes in the Troposphere, Stratosphere, and Mesosphere, and Inter-Layer Interactions. IOP Conference Series Earth and Environmental Science, 386, Article ID: 012003. https://doi.org/10.1088/1755-1315/386/1/012003

Qin, Y., Tonnesen, G. S., \& Wang, Z. (2004). Weekend/Weekday Differences of Ozone, $\mathrm{NO}_{\mathrm{x}}, \mathrm{CO}, \mathrm{VOCs}, \mathrm{PM}_{10}$ and the Light Scatter during Ozone Season in Southern California. Atmospheric Environment, 38, 3069-3087. https://doi.org/10.1016/j.atmosenv.2004.01.035

Ravishankara, A. R., Daniel, J. S., \& Portmann, R. W. (2009). Nitrous Oxide $\left(\mathrm{N}_{2} \mathrm{O}\right)$ : The Dominant Ozone-Depleting Substance Emitted in the 21st Century. Science, 326, 123-125. https://doi.org/10.1126/science.1176985

Rozema, J., Boelen, P., \& Blokker, P. (2005). Depletion of Stratospheric Ozone over the Antarctic and Arctic: Responses of Plants of Polar Terrestrial Ecosystems to Enhanced UV-B, an Overview. Environmental Pollution, 137, 428-442. 
https://doi.org/10.1016/j.envpol.2005.01.048

Sivasakthivel, T., \& Reddy, K. K. S. K. (2011). Ozone Layer Depletion and Its Effects: A Review. International Journal of Environmental Science and Development, 2, 30-37. https://doi.org/10.7763/IJESD.2011.V2.93

Solanki, S. K. (2003). Sunspots: An Overview. The Astronomy and Astrophysics Review, 11, 153-286. https://doi.org/10.1007/s00159-003-0018-4

Solomon, S., Haskins, J., Ivy, D. J., \& Min, F. (2014). Fundamental Differences between Arctic and Antarctic Ozone Depletion. Proceedings of the National Academy of Sciences of the United States of America, 111, 6220-6225.

https://doi.org/10.1073/pnas.1319307111

Tilmes, S., Müller, R., Engel, A., Rex, M., \& Russell, J. M. (2005). Chemical Ozone Loss in the Arctic and Antarctic Stratosphere between 1992 and 2005. Geophysical Research Letters, 33, L20812. https://doi.org/10.1029/2006GL026925

Wargan, K., Orbe, C., Pawson, S., Ziemke, J. R., Oman, L. D., Olsen, M. A., Coy, L., \& Knowland, K. E. (2018). Recent Decline in Extratropical Lower Stratospheric Ozone Attributed to Circulation Changes. Geophysical Research Letters, 45, 5166-5176.

https://doi.org/10.1029/2018GL077406

Willett, H. C. (1962). The Relationship of Total Atmospheric Ozone to the Sunspot Cycle. Journal of Geophysical Research, 67, 661-670. https://doi.org/10.1029/JZ067i002p00661

Zoran, M. A., Savastru, R. S., Savastru, D. M., \& Tautan, M. N. (2020). Assessing the Relationship between Ground Levels of Ozone $\left(\mathrm{O}_{3}\right)$ and Nitrogen Dioxide $\left(\mathrm{NO}_{2}\right)$ with Coronavirus (COVID-19) in Milan, Italy. Science of the Total Environment, 740, Article ID: 140005. https://doi.org/10.1016/j.scitotenv.2020.140005 